To cite: JD Mujuzi 'The admissibility in Namibia of evidence obtained through human rights violations' (2016) 16

\title{
The admissibility in Namibia of evidence obtained through human rights violations
}

\author{
Jamil D Mujuzi* \\ Professor of Law, Faculty of Law, University of the Western Cape, South Africa
}

\section{Summary}

Unlike the case in other African countries, such as South Africa, Kenya and Zimbabwe, the Namibian Constitution does not require courts to exclude evidence obtained through human rights violations if the admission of that evidence would render the trial unfair or would be detrimental to the administration of justice. The only article in the Namibian Constitution dealing with the issue of evidence is article 12(1)(b), which provides that '[n]o persons shall be compelled to give testimony against themselves or their spouses, who shall include partners in a marriage by customary law, and no court shall admit in evidence against such persons' testimony which has been obtained from such persons in violation of article $8(2)(b)$ hereof'. However, Namibian courts have invoked the criteria (set out in the Constitutions of South Africa, Kenya and Zimbabwe) in determining whether or not to admit evidence obtained through human rights violations. This article deals with the jurisprudence emanating from Namibian courts dealing with evidence obtained through human rights violations, and highlights the challenges that courts have grappled with in dealing with such evidence. The issues discussed are the relevant provisions relating to the admission of evidence obtained through violating human rights; the tests courts have developed to decide whether or not to admit evidence obtained through human rights violations; the right to remain silent at the time of arrest; the accused's right not to incriminate himself at the trial; the right to consult a lawyer before making 
a statement; and evidence obtained through violating the rights to freedom from torture, cruel, inhuman or degrading treatment. It is recommended that Namibia may have to amend its Constitution to provide, inter alia, for criteria to be used in deciding whether or not to admit evidence obtained through human rights violations.

Key words: evidence; admissibility; Namibia; human rights violations; fair trial; obtained

\section{Introduction}

One of the features of some of the constitutions that were adopted in African countries in the 1990s is that they specifically dealt with the issue of the accused's right to a fair trial. ${ }^{1}$ This could be attributed to the fact that by that time some human rights treaties which had been ratified by some of these countries deal with the issue of the right to a fair trial. These include the International Covenant on Civil and Political Rights (ICCPR) ${ }^{2}$ and the African Charter on Human and Peoples' Rights (African Charter). ${ }^{3}$ Some of the constitutions of countries such as Cape Verde, Ethiopia, Guinea-Bissau, Liberia, Mozambique, Somalia and Sudan require courts to exclude evidence obtained through the violation of certain human rights. ${ }^{4}$ There appears to be a new development in Africa to the effect that the drafters of constitutions have started to address the relationship

See C Heyns \& M van der Linde (eds) Human rights law in Africa (2004).

Art 14.

Art 7.

See, eg, art 33(6) of the Constitution of Cape Verde (1980) which provides that '[a]II evidence obtained by torture; coercion; assault on physical or moral integrity; illegal invasion of correspondence, telephone, domicile, or privacy, or other illicit means, shall be null and void'. Art 19(5) of the Constitution of Ethiopia (1994) provides that '[p]ersons arrested shall not be compelled to make confessions or admissions which could be used in evidence against them. Any evidence obtained under coercion shall not be admissible.' Art 35(6) of the Constitution of GuineaBissau 1984 provides that '[a]ny evidence or confession ... obtained by torture, coercion, or physical or mental harm shall be null and void'. Art 21(c) of the Constitution of Liberia (1986) provides that '[e]very person suspected or accused of committing a crime shall immediately upon arrest be informed in detail of the charges, of the right to remain silent and of the fact that any statement made could be used against him in a court of law. Such person shall be entitled to counsel at every stage of the investigation and shall have the right not to be interrogated except in the presence of counsel. Any admission or other statements made by the accused in the absence of such counsel shall be deemed inadmissible as evidence in a court of law.' Art 65(3) of the Constitution of Mozambique (2004) provides that '[a]ll evidence obtained through the use of torture, coercion, offences against the physical or moral integrity of the person, the abusive intrusion into their private and family life or into their home, correspondence or telecommunications, shall be invalid'. Art 35(4) of the Constitution of Somalia (2012) provides that '[e]very person may not be compelled to self-incriminate, and a verdict may not be based on evidence acquired by means of coercion'. Art 156(c) of the Constitution of Sudan provides that '[p]ersonal privacy is inviolable and evidence obtained in violation of such privacy shall not be admissible in the court of law'. 
between obtaining evidence and the right to a fair trial. For example, the Constitutions of South Africa, ${ }^{5}$ Kenya $^{6}$ and Zimbabwe $^{7}$ deal directly with the issue of the impact that evidence obtained through human rights violations could have on the fairness of the trial or the administration of justice. In all these countries, courts are obliged ${ }^{8}$ to exclude evidence obtained through the violation of any right in the Bill of Rights if the admission of the evidence would render the trial unfair or be detrimental to the administration of justice or to the interests of justice. For example, in Shamduth Singh \& Others $v$ The State, ${ }^{9}$ the South African Supreme Court of Appeal held: ${ }^{10}$

Section 35(5) of the Constitution does not provide for automatic exclusion of unconstitutionally obtained evidence. Evidence must be excluded only if it (a) renders the trial unfair; or (b) is otherwise detrimental to the administration of justice.

5 Sec 35(5) of the 1996 Constitution of South Africa provides that '[e]vidence obtained in a manner that violates any right in the Bill of Rights must be excluded if the admission of that evidence would render the trial unfair or otherwise be detrimental to the administration of justice'.

6 Art 50(4) of the 2010 Constitution of Kenya provides that [e]vidence obtained in a manner that violates any right or fundamental freedom in the Bill of Rights shall be excluded if the admission of that evidence would render the trial unfair, or would otherwise be detrimental to the administration of justice'. Jurisprudence has started to emerge from Kenyan courts on art 50(4), including Republic $v$ John Kithyululu [2016] eKLR (23 March 2016); Martin Musyoka Mutia v Republic [2016] eKLR 1 (22 January 2016); Charles Enos Makokha $v$ Republic [2015] eKLR (5 February 2015); Stephen Ouma Ambogo $v$ Attorney-General [2014] eKLR (21 March 2014); Oluoch Dan Owino \& 3 Others v Kenyatta University [2014] eKLR (5 December 2014); Thoya Kitsao v Republic [2015] eKLR (4 December, 2015); NMA v Republic [2016] eKLR (17 February 2016); Michael Sistu Mwaura Kamau \& 12 Others $v$ Ethics and Anti-Corruption Commission \& 4 Others [2016] eKLR (9 March 2016); Mary Ngechi Ng'ethe v Attorney-General \& Another [2012] eKLR (25 October, 2012); and Robert Muli Matolo v Republic [2015] eKLR 1.

$7 \mathrm{Sec} 70$ (3) of the 2013 Constitution of Zimbabwe provides that '[i]n any criminal trial, evidence that has been obtained in a manner that violates any provision of this chapter must be excluded if the admission of the evidence would render the trial unfair or would otherwise be detrimental to the administration of justice or the public interest'.

8 Once a court finds that the admission of evidence would render the trial unfair or would be detrimental to the administration of justice, it must exclude that evidence irrespective of the seriousness of the offence the accused is alleged to have committed. Eg, in Magwaza v S [2015] 2 All SA 280 (SCA), the appellant was not adequately informed of his rights to remain silent and to consult a lawyer before he confessed to a robbery and, in excluding evidence, the South African Supreme Court of Appeal held: 'I accept that particularly in the current state of endemic violent crime, the public reaction to the exclusion of such evidence is likely to be one of outrage. But we need to remind ourselves that $s$ 35(5) is designed to protect "even those suspected of conduct which would put them beyond the pale"' (para 22).

9 [2016] ZASCA 37 (24 March 2016).

10 Shamduth Singh (n 9 above) para 16. 
Courts consider various factors in deciding whether or not the admission of unconstitutionally-obtained evidence would render a trial unfair or be detrimental to the administration of justice. ${ }^{11}$ In other words, a value judgment has to be made before unconstitutionallyobtained evidence is excluded. ${ }^{12}$ In Namibia, the Constitution ${ }^{13}$ is silent on how courts should deal with evidence obtained through the violation of human rights. Article 12(1)(f) of the Constitution provides:

No persons shall be compelled to give testimony against themselves or their spouses, who shall include partners in a marriage by customary law, and no court shall admit in evidence against such persons testimony which has been obtained from such persons in violation of article $8(2)(b)$ hereof.

Article $8(2)(b)$ provides that '[n]o persons shall be subject to torture or to cruel, inhuman or degrading treatment or punishment'. Namibian courts have started to develop jurisprudence dealing with articles $12(1)(f)$ and $8(2)(b)$. The purpose of this article is to highlight this jurisprudence and to suggest ways in which the court's jurisprudence could be strengthened and the Constitution amended to strike a proper balance, in the fight against crime, between obtaining evidence in violation of human rights, on the one hand, and ensuring that the admissibility of such evidence does not violate the accused's right to a fair trial or is detrimental to the administration of justice, on the other.

\section{Jurisprudence emanating from Namibian courts on evidence obtained through the violation of human rights}

In this section of the article, I highlight the jurisprudence emanating from Namibian courts on the relationship between evidence obtained through the violation of human rights and the accused's right to a fair trial or the administration of justice. Where feasible, the author will deal with the cases in chronological order. It should be noted that the Constitution of Namibia came into effect in March 1990. The author first discusses the case which dealt with the relevant legal provisions

11 In Magwaza (n 8 above) para 15, the South African Supreme Court of Appeal held: 'Although s 35(5) of the Constitution does not direct a court ... to consider "all the circumstances" in determining whether the admission of evidence will bring the administration of justice into disrepute, it appears to be logical that all relevant circumstances should be considered ... A number of factors to be considered in the determination of whether the admission of evidence will bring the administration of justice into disrepute [including]: the kind of evidence that was obtained; what constitutional right was infringed; was such infringement serious or merely of a technical nature and would the evidence have been obtained in any event.' See also Shamduth Singh (n 9 above) para 18.

12 See generally PJ Schwikkard \& SE van der Merwe Principles of evidence (2016) 229278.

13 Of 1990. 
on the issue of evidence obtained through the violation of human rights.

\subsection{Relevant legal provisions}

As mentioned earlier, the Namibian Constitution does not require courts to exclude evidence which has been obtained through the violation of human rights. In this section, the author will illustrate the relevant constitutional and legislative provisions which courts have invoked to decide whether or not evidence obtained through human rights violations is admissible. The first case in which the issue of evidence obtained through human rights violations arose was that of $S \vee$ Minnies and Another. ${ }^{\top 4}$ The Court, on the basis of section 218 of the Criminal Procedure Act, dealt with a pointing-out (of stolen goods and the place where they had been buried) ${ }^{15}$ that had been obtained through torture by the police from the accused. This section provides:

(1) Evidence may be admitted at criminal proceedings of any fact otherwise in evidence, notwithstanding that the witness who gives evidence of such fact, discovered such fact or obtained knowledge of such fact only in consequence of information given by an accused appearing at such proceedings in any confession or statement which by law is not admissible in evidence against such accused at such proceedings, and notwithstanding that the fact was discovered or came to the knowledge of such witness against the wish or will of such accused.

(2) Evidence may be admitted at criminal proceedings that anything was pointed out by an accused appearing at such proceedings or that any fact or thing was discovered in consequence of information given by such accused, notwithstanding that such pointing out or information forms part of a confession or statement which by law is not admissible in evidence against such accused at such proceedings.

The effect of the above section is that, if a court finds that a confession is inadmissible, it may admit a fact or a pointing-out discovered on the basis of such a confession. The question that arose in this case was whether a pointing-out that occurred after the torture of the accused was admissible. The Court held that, under section 218 it had a discretion whether or not to admit evidence obtained as a result of an inadmissible statement or confession. ${ }^{16}$ The Court observed: ${ }^{17}$

Where the evidence is obtained by torture, it would bring the administration of justice into disrepute if such evidence were admitted. This affords adequate grounds, in my view, for exercising such a discretion

141990 NR $177(\mathrm{HC})$.

15 In Minnies (n 14 above) 192, the Court defined a pointing-out in the following terms: 'A "pointing-out" takes place when the accused has physically drawn the attention of the witness to a place or a thing, by some gesture or movement. It could include the accused leading the witness to a place, and describing to him then what to do to ascertain the location of a thing.'

16 Minnies 199.

17 As above. 
against the admission of such evidence. The views expressed herein are based on the facts of this case. I do not deal with other forms of illegallyobtained evidence, and do not wish to do so.

The Court added: 'Article $12(1)(f)$ is peremptory in its terms. The Court shall not admit in evidence testimony which has been obtained by torture. ${ }^{18}$ In dismissing the state's argument that the evidence obtained from the accused was admissible, the Court held, inter alia, that that argument 'overlooks one of the main underlying reasons for excluding illegally-obtained evidence, namely, that the use of such evidence can bring the administration of justice into disrepute'. ${ }^{19}$ It is against this background that the Court concluded that ${ }^{20}$

[s] 218 must be interpreted in the light of the provisions of the Constitution. A pointing-out which results from an interrogation conducted in a manner in conflict with art 8(2)(b) of the Constitution cannot be used in evidence against the accused.

There are at least two points worth noting about the Court's finding: first, the reason the Court advanced to exclude the evidence in question, namely, that its admission would be detrimental to the administration of justice. The Court does not explain how the admission of that evidence would be detrimental to the administration of justice, for example, that its admission would encourage the police to violate rights in their bid to obtain evidence. 21 The Court did not hold that the admission of that evidence would have rendered the accused's trial unfair. This is the case even though article 12(1)(f) of the Constitution provides that the accused has a right not to incriminate himself. The second point is that, although the facts of the case dealt with evidence obtained through human rights violations, the Court used an all-encompassing term: 'illegally'-obtained evidence. One has to recall that not all

\section{As above.}

19 As above.

20 As above. The same approach has also been adopted in South Africa. See Matlou \& Another v S [2010] 4 All SA 244 (SCA) para 22. In Mhlongo v S [2015] ZAKZPHC 9 (30 January 2015), the Court held that '[i]t is important, having due regard to section 218(1), that the evidence will only be admissible if the accused submits to a pointing-out after having due knowledge of his rights' (para 9).

21 In South Africa, eg, in S v Tandwa \& Others 2008 (1) SACR 613 (SCA) para 120, the Court explained why the admission of evidence would render the trial unfair or be detrimental to the administration of justice. The Court held that 'admitting real evidence procured by torture, assault, beatings and other forms of coercion violates the accused's fair trial right at its core, and stains the administration of justice. It renders the accused's trial unfair because it introduces into the process of proof against him evidence obtained by means that violate basic civilised injunctions against assault and compulsion. And it impairs the administration of justice more widely because its admission brings the entire system into disrepute, by associating it with barbarous and unacceptable conduct.' In S v Mini \& Others [2015] ZAWCHC 49 (30 April 2015), the South African High Court, in excluding evidence obtained from the accused through assaults, held that 'this judgment will hopefully serve as a reminder to persons involved in investigating crime, whether from the public or private sector, that the courts will not tolerate the extraction of information by violence or threats of violence' (para 10). 
evidence obtained through the violation of human rights is illegallyobtained evidence, and not all the evidence obtained illegally is obtained through violating human rights. ${ }^{22}$ However, on the facts of this case, the evidence had been obtained illegally and in violation of a right in the Bill of Rights. It is, therefore, critical that a distinction between evidence obtained through human rights violations and that obtained illegally is kept in mind. The author will now deal with the test for excluding evidence obtained through the violation of human rights in Namibia.

\subsection{Test(s) for excluding evidence obtained through the violation of human rights}

As mentioned above, the Namibian Constitution does not provide for the criteria courts have to invoke to decide whether or not to exclude unconstitutionally-obtained evidence. Namibian courts have adopted the South African criteria regarding whether the admission of such evidence would render the trial unfair or be detrimental to the administration of justice. The issue whether a violation of any right in the Bill of Rights would vitiate the accused's trial was addressed by the Supreme Court in Sv Shikunga \& Another. ${ }^{23}$ The Court held that the proper approach to dealing with evidence obtained irregularly is the following: 24

Even if it is assumed that the breach of every constitutional right has the same effect on a conviction which is attacked on appeal, it does not follow that in all cases that consequence should be to set aside the conviction. I am not persuaded that there is justification for setting aside on appeal all convictions following upon a constitutional irregularity committed by a trial court. It would appear to me that the test proposed by our common law is adequate in relation to both constitutional and non-constitutional errors. Where the irregularity is so fundamental that it can be said that in effect there was no trial at all, the conviction should be set aside. Where one is dealing with an irregularity of a less severe nature then, depending on the impact of the irregularity on the verdict, the conviction should either stand or be substituted with an acquittal on the merits. Essentially the question that one is asking in respect of constitutional and non-constitutional irregularities is whether the verdict has been tainted by such irregularity. Where this question is answered in the negative the verdict should stand. What one is doing is attempting to balance two equally compelling claims - the claim that society has that a guilty person should be convicted, and the claim that the integrity of the judicial process should be upheld. Where

22 See Gumede v S (800/2015) [2016] ZASCA 148 (30 September 2016), in which the South African Supreme Court of Appeal discusses the differences between illegally-obtained evidence and unconstitutionally-obtained evidence.

231997 NR 156 (SC).

24 Shikunga (n 23 above) 171-172. In this case, the Court held that sec 217(1)(b)(ii) of the Criminal Procedure Act was unconstitutional. This section provided that if a confession had been made before a magistrate or had been reduced in writing before a magistrate, there was a presumption that it had been made validly. If the accused wanted to challenge the validity of such a confession, he had the burden of proving that the confession had not been validly made. The Court held that the right to be presumed innocent places a duty on the prosecution to prove beyond reasonable doubt that a confession had been made validly. 
the irregularity is of a fundamental nature and where the irregularity, though less fundamental, taints the conviction the latter interest prevails. Where however the irregularity is such that it is not of a fundamental nature and it does not taint the verdict the former interest prevails. This does not detract from the caution which a court of appeal would ordinarily adopt in accepting the submission that a clearly established constitutional irregularity did not prejudice the accused in any way or taint the conviction which followed thereupon.

In this case, the Supreme Court held that not every human rights violation annuls the proceedings. The judicial officer has to consider the seriousness of the violation. The more serious the violation, the more compelling the reason for excluding such evidence. In a subsequent decision, the High Court explained why the record of bail proceedings in which the accused had incriminated themselves without being informed of the right to remain silent was inadmissible at their trial. This is because it would have rendered the trial unfair. In $S v$ Malumo \& 111 Others ${ }^{25}$ the Court held: ${ }^{26}$

The failure to inform the accused persons of the privilege against selfincrimination (in terms of the provisions of s 203) or their right not to be compelled to give evidence against themselves (in terms of art 12(1)(f) of the Namibian Constitution) will in my view render this trial unfair since to allow it would expose the accused persons to cross-examination by the state on the contents of the record of the bail proceedings in circumstances where a fundamental right of the accused persons had been violated.

In another case, where the accused was not informed of the right to legal aid before making a statement to the police, the Court, in holding that the statement was inadmissible against the accused, held: 27

It is trite that the failure to inform an accused does not in all cases constitute an irregularity; and that this court has a discretion to exclude evidence obtained in violation of an accused's constitutional rights where its admission would render the trial unfair or otherwise detrimental to the administration of justice.

This decision raises four crucial points as far as the issue of admitting evidence obtained through human rights violations is concerned. First, for the test above to be invoked, an accused's constitutional right should have been violated in the process of gathering the evidence in question. This raises the question as to what happens to evidence obtained in violation of a right which is not specifically provided for in the Constitution (for example, the right to remain silent at the time of arrest and the right to consult with a lawyer before making a statement). These rights cannot properly be labelled constitutional rights simply because they are not provided for in the 
Constitution. As the High Court held in Gomes $v$ Prosecutor-General of the Republic of Namibia \& Others, ${ }^{28}$ 'the right to remain silent after arrest and during trial is nowhere specifically mentioned in art 12 [of the Constitution], but it undoubtedly is an important component of a fair trial'. ${ }^{29}$ Second, the judgment appears to suggest that for the evidence to be excluded, it is the accused's constitutional right or rights that should have been violated. This raises the question as to whether evidence obtained as a result of violating the rights of another person may be admissible against the accused. Third, the Court held that it has 'a discretion' to exclude evidence obtained through violating the accused's constitutional right if its admission would render the trial unfair or otherwise be detrimental to the administration of justice. In other words, a court is not obliged to exclude evidence obtained through violating the accused's constitutional right, even if the admission of that evidence would render the trial unfair or otherwise be detrimental to the administration of justice. In countries, such as Kenya, South Africa and Zimbabwe, a court does not have such a discretion. The court must exclude evidence obtained through human rights violations if its admission would render the trial unfair or otherwise be detrimental to the administration of justice. However, the Court held that, on the facts of the case before it, '[t]he admission [of the statement] would render the trial of the accused unfair'. ${ }^{30}$

In the above judgments courts have excluded evidence obtained through human rights violations either because the admission of this evidence would render the trial unfair, or would otherwise be detrimental to the administration of justice. The seriousness of the violation is a factor that has to be considered in deciding whether or not to exclude such evidence.

In $S v$ Sankwasa, ${ }^{31}$ the Court had to decide whether to admit real evidence (diamonds) obtained from the accused at a time when he was not a suspect. After examining the circumstances in which the evidence had been obtained from the accused, the Court held: 'I am satisfied that the admission of the 12 unpolished diamonds in evidence ... would not render the trial unfair and bring the administration of justice into disrepute. ${ }^{132}$ Here the Court sets a test different from that of the cases discussed above, to the effect that evidence obtained through human rights violations has to be excluded if its admission would render the trial unfair or would otherwise be detrimental to the administration of justice. The Court in $S v$ Sankwasa ${ }^{33}$ appears to suggest that, for evidence obtained through violating a constitutional right to be inadmissible, it has to be

(A61/2012) [2013] NAHCMD 240 (9 August 2013).

Gomes (n 28 above) para 9.

Haifiku (n 27 above) para 17.

2013 JDR 1977 (Nm).

Sankwasa (n 31 above) para 42.

As above. 
satisfied that the admission of such evidence would render the trial unfair and bring the administration of justice into disrepute. In other words, both of the two requirements must be met: The fairness of the trial must be affected and, in addition to that, the administration of justice must also be brought into disrepute. It is also important to note that the Court used the phrase to 'bring the administration of justice into disrepute' as opposed to 'detrimental to the administration of justice' which is used in the South African Constitution and the South African jurisprudence relied on by the Court. In the same case, the Court also dealt with the admissibility of a confession the accused made after having been assaulted by the police. In holding that the confession was inadmissible as it had not been made freely and voluntary, as required by section 217 of the Criminal Procedure Act, the Court held: 34

Article 12(1)(f) of the Constitution provides that ... no court shall admit in evidence testimony which has been obtained in violation of article $8(2)(b)$. This court would thus be mandated to exclude evidence which had been obtained as a result of any assault or threat perpetrated in order to persuade the accused to give a statement.

It is beyond dispute that, in terms of article 12(1)(f), a statement made by an accused after an assault or threat of assault would be inadmissible against him for violating his right against selfincrimination. However, although all assaults would undoubtedly violate rights under article $8(2)(b)$, the same cannot be said of all threats. Therefore, in cases of cruel, inhuman or degrading treatment (such as threats that do not amount to violating rights under article $8(2)(b))$, evidence would have to be excluded only on the basis of the first part of article 12(1)(f) of the Constitution. Another important point to note about the judgment is that the Court held that for a confession to be admissible, it is necessary that a proper inquiry be conducted to decide 'whether there was a causal connection between the assault complained of by the accused and his decision to confess'. ${ }^{35}$ Implied in this ruling is the fact that, if there is no causal connection between the human rights violation and the discovery of evidence, the evidence would be admissible unless it has to be excluded on other grounds. The duty is on the accused 'to demonstrate a violation of any of his constitutional rights'. ${ }^{36}$ The issue of specific rights and how courts have dealt with the evidence obtained through their violation will now be considered. 


\subsection{Right to remain silent at the moment of arrest}

Although the Constitution of Namibia provides for several rights of an arrested person, ${ }^{37}$ it contains no provision that an arrested person has the rights to remain silent and to consult with a lawyer before making a statement to the police. The question that arises is whether evidence, for example a statement or an admission, obtained from an arrested person without informing him of the right to remain silent or to consult with a lawyer, is inadmissible. The High Court dealt with this question in the case of $S v$ Kapiya. ${ }^{38}$ According to a state witness, the accused had made an incriminating statement after having been informed by a police officer that he 'was not [to be] forced to answer any questions and that, if he gives a statement, it would be used in a court of law', and that he had 'a right to a legal representative of his own choice or, if he cannot afford it, he could apply for a state lawyer to be appointed'. ${ }^{39}$ It is against this background that 'the accused indicated that he did not need a lawyer and that he would make a statement ${ }^{\prime} .{ }^{40}$ He made the statement which was taken down by the police officer who 'read it back to him and he signed it'. ${ }^{41}$ However, during the trial, the accused challenged the admissibility of the statement in question in that, amongst other grounds, he had not been informed of his right to remain silent and that his statement would be used in court. ${ }^{42}$ The accused's lawyer argued that ${ }^{43}$

[i]t is clear from the evidence that the right to remain silent was not made clear to the accused. She argued that the accused understood that he had a choice to make his statement either to [the police officer] or to court and that such an explanation did not include the right not to make a statement at all.

The Court observed that '[t]he question is whether the Court, on the evidence presented, is satisfied that the accused was informed of his

37 Art 11 provides: '(1) No persons shall be subject to arbitrary arrest or detention. (2) No persons who are arrested shall be detained in custody without being informed promptly in a language they understand of the grounds for such arrest. (3) All persons who are arrested and detained in custody shall be brought before the nearest magistrate or other judicial officer within a period of forty-eight (48) hours of their arrest or, if this is not reasonably possible, as soon as possible thereafter, and no such persons shall be detained in custody beyond such period without the authority of a magistrate or other judicial officer. (4) Nothing contained in sub-article (3) hereof shall apply to illegal immigrants held in custody under any law dealing with illegal immigration: provided that such persons shall not be deported from Namibia unless deportation is authorised by a tribunal empowered by law to give such authority. (5) No persons who have been arrested and held in custody as illegal immigrants shall be denied the right to consult confidentially legal practitioners of their choice, and there shall be no interference with this right except such as is in accordance with the law and is necessary in a democratic society in the interest of national security or for public safety.'

382011 JDR $0776(\mathrm{Nm})$.

39 Kapiya (n 38 above) para 5.

$40 \quad$ Kapiya para 5.

41 As above.

42 Kapiya para 8.

43 Kapiya para 10. 
constitutional right in terms of article $12(1)(f)$ that he was not compelled to give evidence against himself' ${ }^{44}$ The Court held: ${ }^{45}$

The accused, to his credit, candidly admitted that he understood her explanation in respect of his right to legal representation and exercised his right freely. He furthermore admitted that he understood that he did not have to give a statement to the investigating officer. The question, however, is whether it can be said that he understood that he also did not have to give testimony against himself in court. The above forms the basis of some of the concerns raised by the explanation given by [the police officer]. According to her, the accused was rude by not indicating that he understood her. This should have alerted her that perhaps the accused did not fully appreciate what she was explaining to him. The explanation which should have been given to the accused was simply that he has a right to remain silent. This would include the right not to say anything or give a written statement to the police, the right not to give an explanation in terms of section 115 and the right not to testify during trial. The explanation should be given in clear language and should not leave room for confusion. [The police officer's] explanation could be construed in the manner it was understood by the accused, ie that he has to give a statement, if not to her then to the court, which clearly was not a correct interpretation of article 12(1)(f).

Against this background, the judge held that he was 'not convinced that the accused was informed in clear and unambiguous terms of his right to remain silent ${ }^{\prime} .{ }^{46}$ The judge added: ${ }^{47}$

I entertain serious doubt whether [the police officer] gave the accused a proper explanation of his right to remain silent. An accused needs to be informed in clear terms what his right is so as to make an informed choice before it can be said that it was made freely and voluntarily.

This decision has at least three implications. First, it imposes a duty on police officers to inform an arrested person, in clear terms, of the right to remain silent. Second, it extends article 12(1)(f) of the Constitution to arrested persons before they appear in court as accused. This is the case even though article 12(1)(f) provides for one of the rights making up the right to a fair trial. The implication of this is that the accused's right to a fair trial does not begin at the time he appears in court. It begins at the time of arrest. This should be understood against the following background, as the Namibian High Court held in $S v$ Tomas: ${ }^{48}$

The right of an accused to remain silent has always been acknowledged by the courts; more so, since the advent of the Constitution through which a fair trial is guaranteed by article 12(1)(f) - a right that the courts have interpreted to also include the process of bringing an accused person to trial, ie during pre-trial proceedings.

\footnotetext{
$44 \quad$ Kapiya para 12.

45 Kapiya paras 13-14.

46 Kapiya para 15.

$47 \quad$ Kapiya para 16.

482012 JDR $1293(\mathrm{Nm})$ para 45.
} 
The third and, perhaps, debatable implication of the ruling is that a police officer has a duty to inform an arrested person that he has a right to remain silent not only at the police station, but also when he appears before a court and enters a plea of not guilty in terms of section 115 of the Criminal Procedure Act. For one to appreciate the far-reaching consequences of this holding, it is perhaps important to reproduce section 115 of the Criminal Procedure Act. This section provides:

(1) Where an accused at a summary trial pleads not guilty to the offence charged, the presiding judge, regional magistrate or magistrate, as the case may be, may ask him whether he wishes to make a statement indicating the basis of his defence.

(2)(a) Where the accused does not make a statement under subsection (1) or does so and it is not clear from the statement to what extent he denies or admits the issues raised by the plea, the court may question the accused in order to establish which allegations in the charge are in dispute.

(b) The court may in its discretion put any question to the accused in order to clarify any matter raised under subsection (1) or this subsection, and shall enquire from the accused whether an allegation which is not placed in issue by the plea of not guilty, may be recorded as an admission by the accused of that allegation, and if the accused so consents, such admission shall be recorded and shall be deemed to be an admission under section 220 .

(3) Where the legal adviser of an accused on behalf of the accused replies, whether in writing or orally, to any question by the court under this section, the accused shall be required by the court to declare whether he confirms such reply or not.

The Court's ruling that a police officer has to inform an arrested person of the fact that he has a right to remain silent at his trial seems to ignore the fact that under section 115, the police have no role to play in putting questions to the accused. These questions have to be put to the accused by a judicial officer who is required to explain to the accused that he has a right to remain silent. ${ }^{49}$ The ruling also ignores the fact that there are nine different pleas from which an accused may choose, 50 and that there is no guarantee that he will plead not guilty or that, if he pleads not guilty, he will be prosecuted

49 S v Smith 2002 (2) SACR 464(C) para 466; Maqala v S (A382/2014) [2015] ZAGPJHC 80 (14 May 2015) para 2.

50 Sec 106 of the Criminal Procedure Act provides: '(1) When an accused pleads to a charge he may plead (a) that he is guilty of the offence charged or of any offence of which he may be convicted on the charge; or (b) that he is not guilty; or (c) that he has already been convicted of the offence with which he is charged; or (d) that he has already been acquitted of the offence with which he is charged; or (e) that he has received a free pardon under section 327(6) from the State President for the offence charged; or $(f)$ that the court has no jurisdiction to try the offence; or ( $g$ ) that he has been discharged under the provisions of section 204 from prosecution for the offence charged; or (h) that the prosecutor has no title to prosecute. (2) Two or more pleas may be pleaded together except that a plea of guilty may not be pleaded with any other plea to the same charge. (3) An 
at a summary trial. There is also no guarantee that the accused will be prosecuted. The decision whether or not to prosecute a person suspected of committing an offence lies with the prosecution and not the police. ${ }^{51}$ Police officers, most of whom are not lawyers, should not be expected to understand the choices the accused has under section 115. The complex nature of this section is evidenced by the fact that there are many cases in which magistrates have misunderstood it. ${ }^{52}$ In the author's opinion, the police should only be obliged to inform the arrested person that he has a right not to make a statement to the police. They should not, however, tell him that, if he does not make a statement at the police station, he would have to make one in court. When an accused appears in court and section 115 applies, the duty is on the presiding judicial officer to explain the section to the accused and his right to remain silent. ${ }^{53} \mathrm{~A}$ police officer should not be expected to give legal advice to the accused. ${ }^{54}$ Another point emerging from the above judgment ( $S \vee$ Kapiya) is that the Court does not explain why the statement in question should be inadmissible. Is this because of the fact that its admission would render the accused's trial unfair? This omission could be attributed to the fact that article 12(1)(f) does not state the purpose or purposes for which evidence obtained through human rights violations should be excluded. As mentioned earlier, the Constitutions of Kenya, South Africa and Zimbabwe expressly state the purposes for which evidence obtained through human rights violations should be excluded.

accused shall give reasonable notice to the prosecution of his intention to plead a plea other than the plea of guilty or not guilty, and shall in such notice state the ground on which he bases his plea: Provided that the requirement of such notice may be waived by the attorney-general or the prosecutor, as the case may be, and the court may, on good cause shown, dispense with such notice or adjourn the trial to enable such notice to be given. (4) An accused who pleads to a charge, other than a plea that the court has no jurisdiction to try the offence, or an accused on behalf of whom a plea of not guilty is entered by the court, shall, save as is otherwise expressly provided by this Act or any other law, be entitled to demand that he be acquitted or be convicted.'

51 See generally Ex Parte: Attorney-General In Re: Constitutional Relationship Between Attorney-General and the Prosecutor-General 1995 (8) BCLR 1070 (NmS); Kahorere \& Others $v$ Minister of Home Affairs \& Others (A292/2008) [2011] NAHC 44 (22 February 2011) para 16.

52 See, eg, S v Tjipetekera (CR 75/2012) [2012] NAHC 291 (11 September 2012); S v Kau \& Others (SA 1/93) [1993] NASC 2; 1995 NR 1 (15 October 1993); S $v$ Gqagqa (17/15, SH232/14) [2015] ZAGPPHC 585 (7 May 2015) para 13; S $v$ Ramokone 1995 (1) SACR 634(O); S v Masike 1996 (2) SACR 245(T).

$53 S v$ Christiaan (Case CR 53/08) [2008] NAHC 44 (27 May 2008) para 3; State $v$ Petrus (Siboleks J) [2016] NAHCMD 93 (5 April 2016) para 3.

$54 S$ v Mngeni 2013 (1) SACR 583 (WCC) para 114. The Court held: 'It is not expected of the police officer taking a confession or statement to offer an accused person any legal advice as to how best to exercise his or her rights. There is no duty on the police to provide any further assistance than what is required and set out in the Constitution, as long as the process is fair and the accused is not deliberately set up in such a manner that he or she would be forced against his or her will not to exercise his or her rights in terms of the Constitution.' 


\subsection{Type of evidence: Self-incrimination}

Related to the above is the issue of the kind of evidence governed by article 12(1)(f) if it is not read in tandem with article 8(2)(b). As mentioned earlier, article 12(1)(f) states:

No persons shall be compelled to give testimony against themselves or their spouses, who shall include partners in a marriage by customary law, and no court shall admit in evidence against such persons' testimony which has been obtained from such persons in violation of article 8(2)(b) hereof.

Article 21(1)(f) deals with the following issues in the context of criminal law:

(1) It protects the accused's right against self-incrimination. ${ }^{55}$ However, it does not prevent the accused from making an incriminating statement, admission or confession as long as he or she has done so voluntarily.

(2) It provides that a person cannot be compelled to give evidence against his or her spouse. However, it does not mean that such spouse is not a competent witness for the prosecution. What it means is that such spouse is not a compellable witness for the prosecution. ${ }^{56}$ It also means that a person is a compellable witness for his or her spouse. In light of the fact that Namibian law does not recognise same-sex relationships, 57 people in such relationships, for example, if they have contracted their marriage or have entered into a civil union outside Namibia, are not protected by article 12(1)(f). Thus, they will be compellable witnesses for the prosecution.

(3) Article 12(1)(f) is silent on the accused's right to remain silent at his trial, and the issue of whether a presiding judicial officer has a duty to explain to an accused who has not pleaded guilty that he has the right to remain silent is still contentious. ${ }^{58}$ However, there is jurisprudence from Namibian courts to the effect that an accused has a right to remain silent at his trial. In $S v$ Tomas, $^{59}$ the Court held: 60

55 See Hendricks \& Others v Attorney-General, Namibia \& Others 2002 NR 353 (HC) 354.

56 See $S$ v Du Preez (CC 64/07) [2009] NAHC 70 (18 June 2009) para 13, where the accused's wife was a state witness in a case against the accused. In Dladla v S 2011 (1) SACR 80 (KZP) para 10, the Court held that '[a] witness is competent if he or she may lawfully give evidence. Generally, everyone is presumed to be a competent and compellable witness. A compellable witness is one who is competent and in addition can be forced to testify under the pain of punishment in terms of section 189 of the Act.'

57 See Chairperson of the Immigration Selection Board v Frank \& Another (SA8/99, SA8/ 99) [2001] NASC 1 (5 March 2001).

58 See S v Kasanga (CA2/05, CA2/05) [2005] NAHC 46 (2 December 2005), discussing S v Shikongo \& Another 1999 NR 375 (SC).

59 (CC 02/2012) [2012] NAHC 214 (30 July 2012).

60 Tomas (n 59 above) para 45. 
The right of an accused to remain silent has always been acknowledged by the courts; more so, since the advent of the Constitution through which a fair trial is guaranteed by article12(1)(f) - a right that the courts have interpreted to also include the process of bringing an accused person to trial, ie during pre-trial proceedings.

In Gomes $v$ Prosecutor-General of the Republic of Namibia \& Others, 61 the Court held that 'the right to remain silent after arrest and during trial is nowhere specifically mentioned in art 12 , but undoubtedly it is an important component of a fair trial'. ${ }^{62}$ In $S \vee v$ Neidel and Others, ${ }^{63}$ the Court held that the accused had 'exercised their constitutional right to remain silent' by not testifying at the trial. ${ }^{64}$ The Court added that ' $\mathrm{t}$ ] he accused exercising their right to remain silent is not a warrant for the conclusion that they are guilty'. ${ }^{65}$ Likewise, in $S v$ Gariseb and Another, ${ }^{66}$ the Court held that '[a]fter the state closed its case, the two accused persons exercised their constitutional rights to remain silent. They called no witnesses. ${ }^{.67}$ The same approach was taken in $S v$ Shuudeni.68 In $S v$ Namweya, ${ }^{69}$ where there was compelling evidence that the accused had committed murder, the Court observed that the accused had not called witnesses and 'exercised his right to remain silent'. ${ }^{70}$ The prosecution 'criticised the accused for having decided to remain silent in the face of the evidence led by the state establishing a prima facie case' ${ }^{71}$ The Court held that '[a]lthough the accused is not obliged to give evidence, I am of the view that this is not an appropriate case where the accused can safely opt to exercise his right to remain silent ${ }^{\prime}{ }^{72}$

The accused's right to remain silent extends to sentencing proceedings. ${ }^{73}$ In the above cases, and in many other High Court ${ }^{74}$

61 Gomes (n 28 above).

62 Gomes para 9.

63 (CC 21/2006) [2011] NAHC 232 (27 July 2011).

64 Neidel (n 63 above) para 14.

65 Neidel para 15.

66 (CC 16/2010) [2013] NAHCMD 25 (30 January 2013).

67 Gariseb (n 66 above) para 49.

68 (CC 09/2011) [2012] NAHC 183 (3 July 2012) 19. In Shuudeni, the Court held that '[t]he accused opted to exercise his constitutional right to remain silent'.

69 (CC 13/2013) [2013] NAHCMD 333 (14 November 2013).

70 Namweya (n 69 above) para 20.

71 Namweya para 23.

72 Namweya para 27.

73 S v Kharigub (CC 17/2010) [2012] NAHC 106 (8 March 2012) para 4, where the Court held that ' $[\mathrm{t}] \mathrm{he}$ accused opted to exercise his right to remain silent in mitigation'.

74 S v Farmer (CC 6/2010) [2013] NAHCMD 95 (11 April 2013) para 15; S v Malumo \& Others (CC 32/2001) [2013] NAHCMD 33 (11 February 2013) para 29; S v Stephanus \& Others (CA 68/2000) [2012] NAHC 75 (19 March 2012) para 14; S V Karirao (CC 18/2010) [2011] NAHC 152 (6 June 2011) para 12; Eric v S Case CA 56/2011 (6 February 2012) para 9; S v Mwilima (CC 67/07/2008) [2011] NAHC 246 (18 August 2011); S V Erastus \& Others (CR 33/2011) [2011] NAHC 117 (13 April 2011) para 6; S v Dausab (CC 38/2009) [2010] NAHC 90 (20 September 2010) para 23; S V Goagoseb \& Another (CC6/08) [2010] NAHC 37 (8 June 2010) 
and Supreme Court ${ }^{75}$ decisions, Namibian courts have expressly stated that an accused has the right to remain silent at his trial. In some cases, courts have referred to this right as a 'constitutional right', whereas in others this has not been the case. Whether the right to remain silent is a 'constitutional right', as some courts have held, is open to debate in light of the fact that the Constitution does not expressly provide for this right. However, in $S v$ Katari, $^{76}$ where the accused chose not to testify in his defence and closed his case without rebutting the evidence led by the prosecution, the High Court held that the fact that the accused has rights to be presumed innocent and not to incriminate himself 'does not mean that an accused's election to remain silent in the face of incriminating evidence against him is without consequence in the overall assessment of the evidence by the court'. ${ }^{77}$

(4) The first part of the section does not use the word 'accused' and does not state that it is only applicable to criminal cases or to trials. ${ }^{78}$ In fact, the words 'accused' or 'trial' are absent from the whole section. If it were to be advanced, an argument that section 12(1)(f) could, therefore, be extended to situations such as commissions of inquiry or disciplinary hearings should not be easily dismissed. Had the drafters of the Constitution wanted to restrict this to criminal cases, they would expressly have done so, as they did in article 12(1)(b), where the word 'accused' is used; article $12(1)(d)$, where it is very clear that it is applicable to criminal trials; article 12(1)(e), where the word 'trial' is used; and articles 12(2) and (3), which are only applicable to criminal cases. In Gases \& Others $v$ The Social Security Commission \& Others, ${ }^{79}$ the Court dealt with the question whether article 12(1)(e) was applicable to an insolvency inquiry which was conducted on the basis of section $417(2)(b)$ of the Companies Act. ${ }^{80}$ This section compelled the person appearing before such an inquiry to answer incriminating questions notwithstanding the fact that the answers

para 47; S v Morkel (CC 40/97) [1996] NAHC 43 (3 April 1996) (the Court observed that the accused had a fundamental right to remain silent); and $\mathrm{S} V$ Kapolo (CC 05/2012) [2013] NAHCNLD 28 (16 May 2013).

75 In Auala v S (SA 42/2008) [2010] NASC 3 (27 April 2010) para 5, the Supreme Court observed that 'at the trial the appellant exercised his right to remain silent and thus did not testify'.

762006 (1) NR 205 (HC).

77 Katari (n 76 above 210. The Court added that '[w] prima facie case against an accused which remains uncontradicted, the court may, unless the accused's silence is reasonably explicable on other grounds, in appropriate circumstances conclude that the prima facie evidence has become conclusive of his or her guilt'.

78 In S v Thambapilai 2013 JDR 1415 (Nm) para 10: 'It must be expressly pointed out that article 12(1)(f) of the Constitution proved the protection against selfincrimination to an accused for not being compelled to give evidence against himself.'

792005 NR $325(\mathrm{HC})$.

80 Act 61 of 1973. 
given at the inquiry may be used against him as evidence at a subsequent criminal trial. Section $417(2)$ (b) was to the following effect:

(1) In any winding-up of a company unable to pay its debts, the Court may at any time after it has made a winding-up order summon before it any director or officer of the company or person known or suspected to have in his possession any property of the company or believed to be indebted to the company, or any person whom the Court deems capable of giving information concerning the trade, dealings, affairs or property of the company.

(2) (a) The Court may examine any person summoned under ss (1) on oath or affirmation concerning any matter referred to in that subsection, either orally or on written interrogatories, and may reduce his answers to writing and require him to sign them.

(b) Any such person may be required to answer any question put to him at the examination, notwithstanding that the answer might tend to incriminate him, and any answer given to any such question may thereafter be used in evidence against him.

(3) The Court may require any such person to produce any books or papers in his custody or under his control relating to the company but without prejudice to any lien claimed with regard to any such books or papers, and the Court shall have power to determine all questions relating to any such lien.

(4) If any person who has been duly summoned under ss (1) and to whom a reasonable sum for his expenses has been tendered, fails to attend before the Court at the time appointed by the summons without lawful excuse made known to the Court at the time of its sitting and accepted by it, the Court may cause him to be apprehended and brought before it for examination.

The applicants argued that section 417(1)(b) was unconstitutional and submitted that the insolvency proceedings should be stayed pending the outcome of a constitutional challenge to section $417(1)(b)$. The Court held that the applicants' challenge regarding the constitutionality of section $417(1)$ (b) was likely to be successful. ${ }^{81}$ However, the Court added: ${ }^{82}$

But does this mean that the applicants are entitled to a stay of the $s 417$ proceedings? I am of the view that the bad part of $s 417(2)(b)$ is clearly severable from the good part. The good part of the section is now accepted across the world, that in certain circumstances a person may be required (in insolvency investigations) to answer a question even though that answer may incriminate him. As in South Africa, and all over the world, the provision of art 12(1)(f) is not an absolute right. Requiring a person to answer, even in circumstances where he may incriminate himself

81 Gases (n 79 above) 333.

82 Gases 337. 
(in the circumstances of an insolvency enquiry), is rationally connected to a legitimate purpose. That is probably the test which any Namibian Court deciding the constitutionality of s 417 will apply. I am also of the view that the applicants do not have any reasonable prospects to declare the good part of $s 417(2)(b)$ unconstitutional. It is a provision, acknowledged to be rationally connected to a legitimate purpose. I see no reason, let alone reasonable prospects, for any Namibian Court to hold otherwise.

The Court added that the inquiry would enable the liquidators to establish where the applicant had put the money that had been missing from the company. ${ }^{83}$ It held further: ${ }^{84}$

In any event, the provisions of the bad part of $s 417(2)(b)$ are not peremptory. The word 'may' clearly indicates that a trial court may still reject the evidence, once the state endeavours to lead such evidence in any criminal trial. I do not suggest that the fact that the bad part of $s 417(2)(b)$ vests the trial court with a discretion whether or not to allow such evidence will save the bad part from being declared unconstitutional, but it is a factor which I am entitled to take into consideration now.

The Court concluded that the applicants' insolvency inquiry under section 417 should proceed and 'if and when criminal proceedings are instituted against the applicants, the courts will probably come to their assistance (by not allowing such incriminating evidence or by declaring the bad part unconstitutional) ${ }^{\prime}{ }^{85}$

Another important question arising in the context of the second part of article 12(1)(f) is whether the testimony obtained from another person, who is not the accused or the spouse of the accused, in violation of article $8(2)(\mathrm{b})$, is admissible against the accused. The second part of article 12(1)(f) appears to be limited to evidence obtained from the accused or from the accused's spouse. This issue will be dealt with later in the article.

Another issue to be noted about article 12(1)(f) is that it is limited to testimonial evidence only. In $S v$ Nassar, ${ }^{86}$ the High Court held that article 12(1)(f) 'refers only to testimonial evidence' ${ }^{87}$ In $S v$ Shipanga $\&$ Another, $^{88}$ the Supreme Court held that article 12(1)(f) of the Constitution was 'peremptory in its terms' and that, in the context of article 12(1)(f), '[t]estimony includes a pointing-out done through an admission or a statement and therefore a pointing-out obtained in violation of art $8(2)(b)$ of the Constitution cannot be used in evidence against the accused'. 89

\footnotetext{
83 As above.

84 As above.

85 Gases 339.

861994 NR 233 (HC).

$87 \quad$ Nassar (n 86 above) 259.

882015 (1) NR 141 (SC).

89 Shipanga (n 88 above) 155.
} 


\subsection{Right to legal representation}

As in the case of the issue of the right to remain silent, the Namibian Constitution does not provide for the right of an arrested person to be informed of his right to consult with a lawyer before making a statement, confession or admission to a police officer. The issue of evidence obtained from an accused by the police without informing him of the right to consult with a lawyer arose in the case of $S \mathrm{~V}$ Gariseb, ${ }^{90}$ where the Court held: ${ }^{91}$

All officers who took the confessions and admissions although they had explained the right to legal representation there is no indication that they had also explained that the accused persons had a right to apply for legal aid ... The Constitution did not specifically provide for a right to legal aid. It provides for a fair trial in article 12 which includes the right to legal representation and the right for one not to incriminate himself or herself. The confessions and admissions were obtained in violation of article 12 of the Constitution because accused 1 was effectively compelled to incriminate himself due to the assaults he had endured. Again both accused were not properly informed of their rights to legal representation and the failure to explain the right to apply for legal aid rendered the confessions and admissions made by the accused inadmissible.

The Court also held that a confession or admission made by one of the accused as a result of an assault was inadmissible on the basis of article 12(1)(f) read with article 8(2)(b) of the Constitution. In Haifiku, the High Court held that, because of the relatively low level of the accused's education (having completed Grade 9) and his young age at the time of arrest (he was 18 years old), '[t]his evidence does not entitle this court to assume that he was aware of his rights'. ${ }^{92}$ This implies that, if the accused is not informed of his right to remain silent and his right to consult a lawyer before making a statement, but there is evidence that he was aware of his rights, the evidence obtained from him may be admissible. However, in $S v$ Dausab, ${ }^{93}$ where the police officers did not inform the accused of his rights before he made statements as they assumed that he knew his rights since he had been arrested before and been informed of his rights, the Court, in holding that the statements were inadmissible, observed: 94

The three officers had a legal obligation to make sure that the rights were properly explained to the undefended accused in the language that he understands before he started telling them what happened regarding the allegations he is facing, which they conceded they didn't do. This shortcoming is fatal as it militates against the accused's constitutional right to a fair trial enshrined in art 12(1)(f) of the Constitution. The fact that at the time of the accused's arrest ... he was already aware of his rights from his previous arrests cannot remedy the damage caused by such a failure.

902013 JDR $0083(\mathrm{Nm})$.

91 Gariseb (n 90 above) para 48.

92 Haifiku (n 27 above) para 12.

932014 (3) NR 652 (HC).

94 Dausab (n 93 above) para 9. 
In $S v$ Shipanga, ${ }^{95}$ the Supreme Court held that the general rule was that an accused has to be informed of his right to a lawyer before making a confession or pointing-out. ${ }^{96}$ The Court added that whether or not the accused has decided to waive his right 'depends to a large extent on whether the accused has been informed of his or her constitutional entitlements in connection to the specific procedure (confession or pointing-out) and it is clear that he knowingly chose to proceed to make the confession or the pointing-out without his lawyer'. ${ }^{97}$ The Court referred to the rights under article 12, and held that ' $[t]$ he only exceptional cases relating to the right to be informed regarding legal representation concern lawyers, the educated and those knowledgeable of the said right' ${ }^{98}$ The Court added: ${ }^{99}$

Where the appellant voluntarily indicated his readiness to offer a confession and pointing-out, the police's obligation was to warn him again of his right to legal representation ... and ensure that if he waived his right to legal representation, he knew and understood what he was doing. The latter is a question of fact and has to be established.

It has now become clear that, apart from the fact that the police have to inform the accused of the right to legal representation, they must also inform him of the right to apply for legal aid. However, in another decision, the High Court held that it is the indigent arrested person who should be informed on the right to legal aid. ${ }^{100}$ The Court added that '[i]t is trite that a fair trial includes fair pre-trial procedure and it is important that the right to apply for legal aid should be explained to an unrepresented accused'. ${ }^{01}$ In $S v D e$ Jay, ${ }^{102}$ the accused had a private lawyer and before he made a confession, the magistrate did not inform him that he had a right to legal aid. In holding that the confession was admissible, the High Court held, inter alia: 103

It is very clear from the [evidence before court] that the accused had a lawyer and was aware of the purpose of having him. It follows therefore that his judgment on the choices to make regarding his legal representation was not affected by the magistrate's omission to explain the legal aid part of his rights to legal representation at the beginning of the confession proceedings.

The Court concluded that 'it was the accused's choice not to have his lawyer present at the confession proceedings'. ${ }^{104}$ However, even in cases where an accused has a private lawyer, the police have a duty to

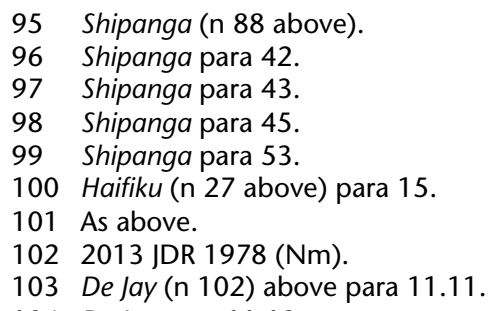


explain to him that he has the right to remain silent, to legal representation and to legal aid, and the accused has to understand this explanation. ${ }^{105}$

\subsection{Evidence obtained through torture or cruel, inhuman, degrading treatment}

Namibia is a state party to the United Nations (UN) Convention against Torture (CAT). Article 15 of the CAT provides:

Each state party shall ensure that any statement which is established to have been made as a result of torture shall not be invoked as evidence in any proceedings, except against a person accused of torture as evidence that the statement was made.

In its Concluding Observations on Namibia's initial report, the Committee against Torture (CAT Committee) called upon Namibia to enact legislation which addresses the need procedurally to exclude all evidence obtained by the use of torture in criminal and all other proceedings, except in proceedings against the perpetrator of torture himself'. ${ }^{106}$ Although article 15 of the CAT refers to 'statement', the practice of the CAT Committee reveals that state parties have an obligation to exclude any statement or statements, ${ }^{107}$ confessions ${ }^{108}$

105 De Jay para 11.15.

106 Report of the Committee against Torture, General Assembly, Official Records, 52nd session, Supplement 44(A/52/44) (1997) para 241(e).

107 Concluding Observations of the Committee against Torture on the Fourth Periodic Report of Israel, CAT/C/ISR/CO/4, 23 June 2009 para 25; Concluding Observations of the Committee against Torture on the Third Periodic Report of Armenia, CAT/C/ARM/CO/3, 6 July 2012 para 16; Concluding Observations of the Committee against Torture on the Combined Fourth to Sixth Periodic Reports of Paraguay, CAT/C/PRY/CO/4-6, 14 December 2011 para 20; Concluding Observations of the Committee against Torture on the Fifth and Sixth Combined Periodic Report of Finland, CAT/C/FIN/CO/5-6, 29 June 2011 para 21; Concluding Observations of the Committee against Torture on the Second Periodic Report of Tajikistan, CAT/C/TJK/CO/2, 21 January 2013 para 13; Concluding Observations of the Committee against Torture on the Third Periodic Report of Senegal, CAT/C/ SEN/CO/3, 17 January 2013 para 13.

118 Concluding Observations of the Committee against Torture on the Second Periodic Report of Yemen, CAT/C/YME/CO/2/Rev.1, 25 May 2010 para 28; Concluding Observations of the Committee against Torture on the Second Periodic Report of Jordan, CAT/C/JOR/CO/2, 25 May 2010 para 30; Concluding Observations of the Committee against Torture on the Second Periodic Report of Cambodia, CAT/C/KHM/CO/2, 20 January 2011 para 28; Concluding Observations of the Committee against Torture on the Initial Periodic Report of Djibouti, CAT/C/DJI/CO/1, 22 December 2011 para 20; Concluding Observations of the Committee against Torture on the Third Periodic Report of Armenia, CAT/ C/ARM/CO/3, 6 July 2012 para 16; Concluding Observations of the Committee against Torture on the Second Periodic Report of the Philippines, CAT/C/PHL/CO/ 2, 29 May 2009 para 23; Concluding Observations of the Committee against Torture on the Initial Report of Ethiopia, CAT/C/ETH/CO/1, 20 January 2011 para 31; Concluding Observations of the Committee against Torture on the Second Periodic Report of the Republic of Moldova, CAT/C/MDA/CO/2, 29 March 2010 para 21; Concluding Observations of the Committee against Torture on the Fourth Periodic Report of Belarus, CAT/C/BLR/CO/2, 7 December 2011 para 18; 
and 'evidence'109 obtained as a result of torture. The Committee has also called upon state parties to exclude evidence obtained through cruel, inhuman and degrading treatment or punishment. ${ }^{110}$ As mentioned earlier, article $8(2)(b)$ of the Constitution provides that '[n]o persons shall be subject to torture or to cruel, inhuman or degrading treatment or punishment'. In Ex parte Attorney-General, In Re: Corporal Punishment by Organs of State, ${ }^{11}$ in which the Namibian Supreme Court held that corporal punishment by organs of state was unconstitutional for violating article $8(2)(b)$ of the Constitution, the Court added that the words in article $8(2)(\mathrm{b})$ have to be read disjunctively and, as a result, article 8 protects the citizen from seven different conditions: torture; cruel treatment; cruel punishment; inhuman treatment; inhuman punishment; degrading treatment; and degrading punishment. ${ }^{112}$ The Court further held: $:^{113}$

The state's obligation is absolute and unqualified. All that is therefore required to establish a violation of article 8 is a finding that the particular statute or practice authorised or regulated by a state organ falls within one or other of the seven permutations of article 8(2)(b).

As mentioned earlier, article 12(1)(f) obliges courts to exclude evidence obtained through violating any right provided for under article $8(2)(b)$ of the Constitution. Namibian courts have held that evidence obtained through torture, whether of the accused or a third

Concluding Observations of the Committee against Torture on the Initial Report of Mauritania, CAT/C/MRT/CO/1, 18 June 2013 para 8(c); Concluding Observations of the Committee against Torture on the Third Periodic Report of Senegal, CAT/C/ SEN/CO/3, 17 January 2013 para 13; Concluding Observations of the Committee against Torture on the Fifth Periodic Report of the Russian Federation, CAT/C/RUS/ CO/5, 11 December 2012 para 10; Concluding Observations of the Committee against Torture on the Combined Fifth and Sixth Periodic Reports of Mexico, CAT/ C/MEX/CO/5-6, 11 December 2012 para 15(a).

109 Concluding Observations of the Committee against Torture on the Second Periodic Report of Lithuania, CAT/C/LTU/CO/2, 19 January 2009 para 18; Concluding Observations of the Committee against Torture on the Second Periodic Report of Cambodia, CAT/C/KHM/CO/2, 20 January 2011 para 28; Concluding Observations of the Committee against Torture on the Combined Third and Fourth Periodic Report of Sri Lanka, CAT/C/LAK/CO/3-4, 8 December 2011 para 11; Concluding Observations of the Committee against Torture on the Initial Report of Ethiopia, CAT/C/ETH/CO/1, 20 January 2011 para 31; Concluding Observations of the Committee against Torture on the Combined Fourth to Sixth Periodic Reports of Paraguay, CAT/C/PRY/CO/4-6, 14 December 2011 para 20; Concluding Observations of the Committee against Torture on the Initial Report of Turkmenistan, CAT/C/TKM/CO/1, 15 June 2011 para 20.

110 For a recent discussion of this jurisprudence, see JD Mujuzi 'Evidence obtained through violating the rights to freedom from torture and other cruel, inhuman, inhuman or degrading treatment in South Africa' (2015) 15 African Human Rights Law Journal 89.

111 (SA 14/90) [1991] NASC 2; 1991 (3) SA 76 (NmSc) (5 April 1991). The Court held that corporal punishment by organs of state on adult and juvenile offenders and in schools was inhuman and degrading punishment within the meaning of art $8(2)(b)$ of the Constitution.

112 Corporal Punishment by Organs of State (n 111 above) 18.

113 Corporal Punishment by Organs of State 19. See also Engelbrecht v Minister of Prisons and Correctional Services 2000 NR 230 (HC) 232. 
party, is inadmissible. ${ }^{114}$ In $S \vee$ Malumo and Others, ${ }^{115}$ the Court referred to the witnesses' evidence, which indicated that they had been assaulted, and held that that evidence was inadmissible. ${ }^{116}$ The Court concluded: 117

I have discussed the issue of torture and degrading and humiliating treatment of witnesses ... and must mention at this stage that had the state presented the evidence of this witness as the only evidence against the accused person I would have disallowed such evidence and would have released the accused.

Evidence will be excluded whether the torture was physical or mental (psychological). ${ }^{118}$ Although the Court does not expressly refer to article 15 of the CAT, its conclusion appears to have been influenced by that treaty. ${ }^{119}$ Apart from evidence obtained through torture, the Supreme Court has also held that evidence obtained through cruel, inhuman and degrading treatment is inadmissible. In Shipanga, ${ }^{120}$ the Supreme Court referred to article 12(1)(f) of the Constitution and held: ${ }^{121}$

That article provides that a court shall not admit in evidence testimony that has been obtained in violation of article $8(2)(b)$ of the Constitution. Testimony includes a pointing-out done through an admission or a statement and therefore a pointing out obtained in violation of article $8(2)(b)$ of the Constitution cannot be used in evidence against the accused.

The Court added that 'article 8(2)(b) prohibits torture cruel, inhuman or degrading treatment or punishment. The second appellant was not subjected to any of the prohibitions contained in article $8(2)(b)$ of the Constitution. ${ }^{122}$ As illustrated earlier, in Minnies, ${ }^{123}$ the Court held that a pointing-out discovered as a result of a confession that had been extracted from the accused through torture is inadmissible notwithstanding the fact that section 218(2) of the Criminal Procedure Act allows a court to admit a pointing-out obtained as a result of an inadmissible confession. What emerges from this jurisprudence is that in Namibia, evidence obtained through torture

114 (CC 32/2001) [2013] NAHCMD 33 (11 February 2013) paras 46-49 (adopting the reasoning of the Supreme Court of Zimbabwe).

115 As above. For the High Court judgment, see S v Malumo (CC 32/2001) [2010] NAHC 20 (1 March 2010). See also S v Malumo \& Others (CC 32/2001) [2011] NAHC 318 (24 October 2011) (the trial-within-a trial to challenge the admissibility of a pointing-out obtained through torture); S v Malumo \& Others (CC 32/2001) [2011] NAHC 220 (19 July 2011) (the trial-within-a trial to determine the admissibility of a statement allegedly obtained through torture).

116 Malumo (n 114 above) para 220.

117 Malumo para 221. See also para 419.

118 Malumo paras 396-397.

119 Malumo paras 46-47 \& 551.

120 Shipanga (n 89 above).

121 Shipanga para 55.

122 Shipanga para 56. See also S v Kukame 2007 (2) NR 815 (HC) paras 4-5; S v Van den Berg 1995 NR 23 (HC) 38.

123 Minnies (n 14 above). 
or cruel, inhuman or degrading treatment will always be inadmissible. The Supreme Court of Zimbabwe has adopted the same approach. ${ }^{124}$ However, the European Court of Human Rights has not been as assertive as the courts in Namibia and Zimbabwe on the question of evidence obtained through cruel, inhuman or degrading treatment. 125

\subsection{Exclusion not limited to rights mentioned in article 12 of the Constitution and evidence obtained by private individuals}

In Namibia, the right to a fair trial does not consist of only those rights enumerated in article 12. The Supreme Court held in Attorney-General of Namibia $v$ Minister of Justice \& Others: ${ }^{126}$

It appears to me that the essential content of art 12 is the right to a fair trial in the determination of all persons' 'civil rights and obligations or any criminal charges against them' and that the rest of the subarticles, which only relates to criminal trials, expounds on the minimum procedural and substantive requirements for hearings of that nature to be fair. A closer reading of art 12 in its entirety makes it clear that its substratum is the right to a fair trial. The list of specific rights embodied in art 12(1)(b)-(f) does not, in my view, purport to be exhaustive of the requirements of the fair criminal hearing and as such it may be expanded upon by the courts in their important task to give substance to the overarching right to a fair trial.

The above reasoning shows that Namibian courts will persist in extending the ambit of the right to a fair trial. In fact, courts have started expanding this ambit. ${ }^{127}$ The case of Sankwasa ${ }^{128}$ raises three important issues in relation to evidence obtained through human

124 Mukoko v Attorney-General [2012] JOL 29664 (ZS).

125 Jallow $v$ Germany Application 54810/00 (11 July 2006).

1262013 (3) NR 806 (SC) para 17.

127 In Shonena $v$ The State (CA 02/2016) [2016] NAHCNLD 67 (8 August 2016) para 7 , the Court held that '[t]he Namibian Constitution provides for a fair trial in article 1 . In my view it entails that, amongst others, any accused should also be able and for that matter should be put in a position to follow what is happening in a trial.' In S v Sheehama (CR 48/2010) [2010] NAHC 101 (24 September 2010) para 7 , the Court stated: 'I will now look at the list of some of the rights that need to be explained to an undefended accused at various stages of the criminal trial: the right to apply for bail; the right to legal representation; the right to the disclosure of docket (witness's statements); the right of the accused in terms of section 112(I)(b) after pleading guilty; the right of the accused at the close of the state's case: such as the right to testify, to call witnesses, to be cross-examined, and to remain silent (as well as the consequences of the last option); the right of the accused in terms of section 115 after he has tendered a plea of not guilty; the right to address Court before judgment; the right to address Court in mitigation of sentence and to reply to the state's submissions in aggravation of sentence; the right of the accused to review and appeal; the right of the accused to seek the state's assistance to bring his witnesses to court; the right of the accused to react to the prosecutor's request for a postponement; the right to be informed of the reasons why he is convicted or acquitted (reasons for judgment) and reasons for the sentence imposed on him.' The Court added that ' $[\mathrm{t}] \mathrm{he}$ above list is not exhaustive, the reason being that law is a developing phenomenon. More rights could still gradually find their way into our justice system' (para 8).

128 Sankwasa (n 31 above). 
rights violations, namely, (i) whether a person who is not a crime suspect is protected by article 12 of the Constitution; (ii) whether security officers of a private company have a duty to inform a suspect of his constitutional rights; and (iii) the stage at which a suspect should be informed of his rights. In this case, during a routine daily and non-discriminatory X-ray examination of all employees leaving company premises, some foreign objects were detected on the accused's body by security officers of a diamond company for which the accused worked. With regard to the first question, the Court held: 129

The principle that a suspect must be informed of his constitutional rights is law, but the point at which point the duty to do so (ie to inform a suspect of his rights) is a factual question. I am of the view that if there is no questioning or request for a suspect to make any statement or pointingout, then there is no duty on the police officer to inform the suspect of his right to remain silent, the right to consult a legal practitioner or his or the right not [to] incriminate himself.

This holding contradicts an earlier High Court decision to the effect that, even if an accused volunteers to make a statement to the police, the police should inform him of his rights, otherwise the statement will be inadmissible in evidence against the accused. ${ }^{130}$ This means that there are two conflicting High Court decisions on this issue. With regard to the second question raised above, the Court held: ${ }^{131}$

It is clear that in this matter the discovery about the presence of the foreign object was made at the time when the appellant was not a suspect and when there was no duty on the security officers to inform the appellant of his constitutional rights, the appellant was not asked to make any statement nor was any statement which is inculpatory of him taken from him, he was also not asked to make any pointing out. I am therefore of the view that there was no duty on [the police officer] in those circumstances to inform the appellant of his constitutional rights under article 12. I am consequently of the view that the police officer did not infringe any of the appellant's constitutional rights guaranteed in article 12 of the Namibian Constitution.

The above holding, therefore, makes it clear that a police officer does not have a duty to inform a non-suspect of the rights under article 12 of the Constitution. In the Court's opinion, these rights only become applicable once the person has become a suspect. The Court gives a detailed explanation of who a suspect is. ${ }^{132}$ With regard to the third question raised above, the Court held: ${ }^{133}$

It is clear that the information which [the police officer] received as to the location of the 'foreign object' on the appellant was obtained while the appellant was a non-suspect and when there was no duty on the Namdeb

129 Sankwasa para 35.

130 De Jay (n 103 above).

131 De Jay para 36.

132 De Jay paras 28-30. See also S v Oroseb (CR 02/2012) [2012] NAHC 3 (20 January 2012).

133 De Jay para 42. 
[Namdeb Diamond Corporation (Pty) Ltd] security officers to inform him of his constitutional rights, he was not questioned or asked to make any statement or give any self-incriminating information.

Implied in this judgment is the fact that security officers of private companies have a duty to inform suspects of their constitutional rights, otherwise evidence obtained by such security officers from those suspects will be inadmissible. However, like police officers, such security officers do not have a duty to inform non-suspects of the rights under article 12 of the Constitution. This is because of the fact that this constitutional provision is not applicable to non-suspects.

The issue of whether or not suspects are protected by the pre-trial rights provision of the South African Constitution, which only refers to the rights of arrested persons, is far from clear. There are three different approaches taken by South African courts: first, that suspects are protected by this provision; ${ }^{134}$ second, that this the provision is only applicable to arrested persons; ${ }^{135}$ and third, that the Supreme Court of Appeal has not found it necessary to express a view on which of the above two approaches is correct. 136

\section{Conclusion and recommendations}

The above discussion has illustrated how courts in Namibia have dealt with evidence obtained through the violation of human rights. It is argued that there is a need to amend the Bill of Rights in the Namibian Constitution to expressly provide for the rights of suspects, arrested persons, detained persons and accused persons. The discussion shows that, because the Constitution does not provide for the rights of these groups, courts are relying on common law and jurisprudence from other countries to expand the rights in the Bill of Rights. The result is that there have been cases where courts have handed down conflicting jurisprudence on the applicability of a given right. In amending the Bill of Rights, reference could be made to the jurisprudence developed by courts - hence not indirectly rendering these judgments useless. Reference could also be made to the Bills of Rights of other countries in Africa, such as Kenya, ${ }^{137}$ South Africa ${ }^{138}$ and Zimbabwe, ${ }^{139}$ the constitutions of which provide for the rights of arrested, detained and accused persons. By specifically providing for the rights of suspects in the Constitution, Namibian courts will not have to grapple with the question of whether the Bill of Rights is only applicable to suspects. It is submitted that there is a need to amend article 12(1)(f) so that it is formulated like the relevant Kenyan,

134 S v Orrie \& Another 2005 (1) SACR 63 (C).

135 Khan v S 2010 (2) SACR 476 (KZP).

136 Lachman v S 2010 (2) SACR 52 (SCA) para 38.

137 Art 49.

$138 \operatorname{Secs} 35(1) \&(2)$.

$139 \operatorname{Sec} 50$. 
Zimbabwean or South African constitutional provisions dealing with evidence obtained through human rights violations. This is so because of at least three considerations, namely, (i) that any relevant right in the Bill of Rights would be expressly included in the equation; (ii) that it would still in certain circumstances be possible to compel spouses to give evidence against one another; and (iii) that courts will have the discretion to exclude evidence on at least one of the two grounds: the fairness of the trial or the administration of justice. The jurisprudence of Namibian courts shows that, in deciding whether or not to admit evidence obtained through human rights violations, the issues of whether or not the admission of evidence would render the accused's trial unfair or would be detrimental to the administration of justice have been considered. This is the case although the Constitution does not authorise the courts to do so. The absence of such a provision has had three results: (i) that some courts have excluded evidence obtained through human rights violations without explaining whether the exclusion of that evidence has been motivated by the need to protect the accused's right to a fair trial or to ensure that the administration of justice would not be put into disrepute; (ii) that some courts have invoked the test of fairness of the trial or detriment to the administration of justice; and (iii) that other courts have invoked one test - the impact the evidence would have on the fairness of the accused's trial. 